\title{
A DEMONSTRATION OF THE POLYMERASE CHAIN REACTION TECHNIQUE IN CLASS TEACHING
}

Yusof R., Abdul Rahman P.S. and Rahim Z.H.A. A demonstration of the polymerase chain reaction in class teaching. Annal Dent Univ Malaya 1999; 6: 1-3

\section{ABSTRACT}

The application of PCR technique in genetic screening was demonstrated using the genetic materials from buccal cells of the students in the class. Two factors were taken into consideration when designing the experiments. The DNA region to be amplified should not be associated with any disease state. This is to eliminate any emotional and ethical problems associated with the experiments. In this practical, the presence and absence of a $38 \mathrm{bp}$ sequence in the intron of COLIA2 gene were studied. The students were also shown on how to analyse the presence of homozygous and heterozygous alleles and the genetic variations that might be observed in the different ethnic groups of students. Another factor was the time taken to complete the experiment. Our experience showed that this experiment would take at least six hours to obtain and analyse the results. It is therefore suitable to be used in class teaching.

Keywords: Polymerase Chain Reaction, DNA, buccal cells, class teaching

\section{INTRODUCTION}

Polymerase Chain Reaction (PCR) is a rapid, inexpensive and simple means of producing relatively large numbers of copies of DNA molecules from minute quantities of source DNA material. DNA is stable and easily isolated compared to RNA and therefore is preferentially used as the target. The DNA samples for the PCR should have at least one intact DNA strand encompassing the region to be amplified and any impurities present that may inhibit the polymerisation step of the PCR reaction should be sufficiently diluted.

PCR technique has been used as a diagnostic tool for the detection of genetic and infectious diseases $(1,2,3)$. Most patients with osteogenesis imperfecta (OI) have mutations in either the COL1A1 or COL1A2 genes. These genes encode the $\alpha 1(\mathrm{I})$ or $\alpha 2(\mathrm{I})$ subunits of type 1 collagen, the major organic component of bone and dentine (4). Watson \& Dalgleish (5) had developed a procedure using PCR technique to detect a length polymorphism which is not associated with any known disease state (6) in the human pro $\alpha 2(\mathrm{I})$ collagen gene locus (COL1 A2).

In this practical, students were given the opportunity to perform the experiments themselves using their own genetic materials extracted from their buccal cells. The presence and absence of a 38 bp sequence in the intron of COLIA2 gene were demonstrated. The experiment which is an extension of the work done by Palmer et al (7) has a different objective. In addition to having hands-on experience of the PCR technique, the students who are of different ethnic groups would have the
Yusof $\mathrm{R}^{+}$, Abdul Rahman $\mathrm{PS}^{+}$and Rahim ZHA*

${ }^{+}$Department of Biochemistry, Medical Faculty, University of Malaya, 50603 Kuala Lumpur

*Department of Oral Biology, Dental Faculty, University of Malaya, 50603 Kuala Lumpur

* Name and address of author to whom requests of reprints should be addressed

opportunity to analyse their results based on ethnic groups and consequently its application to genetic screening.

\section{MATERIALS AND METHODS \\ MATERIALS \\ Chemicals}

Taq DNA polymerase and dNTP were purchased from Fermentas, Tris from GibcoBRL and $\mathrm{NaOH}$ from Amresco.

Subjects used in the study

Subjects used in the study were the Honours year students who are of different ethnic backgrounds. 14 Malays, 15 Chinese and 7 Indians participated in the study.

\section{Preparation of DNA}

Buccal cells were collected by scrapping the inner cheek using a sterilised spoon while in the previous study the buccal cells were collected from mouth wash. More cells were collected by scrapping the inner cheek. This tissue sampling is non-invasive, rapid and painless. The cells collected were then washed with $1 \mathrm{ml}$ distilled water into an eppendorf tube. It was then sedimented at $5000 \mathrm{rev} / \mathrm{min}$ in a microfuge, followed by resuspension in $1 \mathrm{ml}$ of $50 \mathrm{mM}$ $\mathrm{NaOH}$. A $200 \mu \mathrm{l}$ sample was heated at $95{ }^{\circ} \mathrm{C}$ for 20 minutes. The lysate obtained was neutralised with $50 \mu \mathrm{l}$ of $2 \mathrm{M}$ Tris $\mathrm{HCl} \mathrm{pH}$ 7.0. A $20 \mu$ aliquot of this DNA preparation was then used in the PCR reaction mixture.

\section{$P C R$ and PCR product analysis}

The PCR technique used in this practical is a modification of the method described by Palmer et al (7). In this study the reactions were carried out in a $50 \mu$ reaction mixture (master mix) containing $20 \mu \mathrm{l}$ of the DNA extract, $5 \mu \mathrm{M}$ of each primer (sense primer $5^{\prime}$ TCAGTGTATGTTGCTATCAG 3', antisense primer 5'ATTCCACAGTCAACATCAAC 3'), 0.2mM dNTPs, $1.5 \mathrm{mM} \mathrm{MgCl}$, and 5 Units Taq Polimerase. The reactions were performed in an Eppendorf thermal cycler following a program incorporating the following steps: pre-treatment of $95^{\circ} \mathrm{C} 5$ minutes, $94{ }^{\circ} \mathrm{C} 1$ minute, $52^{\circ} \mathrm{C} 1$ minute, $72^{\circ} \mathrm{C}$ 
1.5 minutes for 30 cycles followed by final extension at $72^{\circ} \mathrm{C} 10$ minutes followed by holding at $4{ }^{\circ} \mathrm{C}$.

The product was then analysed on a $2 \%$ agarose gel in the presence of ethidium bromide. A $10 \mu \mathrm{l}$ sample of the PCR product added to $10 \mu \mathrm{l}$ sample buffer containing tracking dye was loaded with a 100 bp ladder molecular weight marker along with the positive and negative controls. The positive control was a $\lambda$-bacteriophage DNA amplified using a specific primer for $\lambda$-DNA and the negative control was the mixture amplified without DNA. The gel was run for 2 hours at 70 volts (5). It was then photographed under UV light.

\section{RESULTS AND DISCUSSION}

The DNA extraction technique used in this experiment was rapid and reliable. The students may scrape their buccal cells directly with a sterile spoon without supervision. Therefore they could use their own DNA extracts which made the experiment more meaningful.

Figure I and II represent the Gel 1 and 2 respectively showing the PCR products in the different lanes (Lane 1-5). The bands for the homozygous and heterozygous alleles would move differently according to the number of base pairs present. From the gels collected, data were compiled and represented in Table I. The students were then shown how to analyse the distribution of homozygous and heterozygous alleles as obtained in the experiment according to their ethnic groups. From the distribution, none of the Malays and Chinese were homozygous for the small alleles which was shown to be present among some of the Indian students.

Heterozygocity appeared to be a common feature in all the ethnic groups. The polymorphism detected in this experiment was known not to be associated with any known disease state. The result therefore should not give rise to any emotional problems. Being first timers, some students may encounter failures in the PCR amplification step which could be due to some technical problems. One of the causes could be that the DNA samples used were already degraded due to contamination with Dnase or overheating of the buccal cells sample during the extraction procedure. Another cause could be failure to include one of the PCR mixture solutions in the preparation of the mastermix. If this happened, the students would be advised to repeat the amplification step using freshly prepared buccal DNA samples. The whole experiment took six hours. This length of time would fit easily into the Honours year students' time-table.

Figure I and II represent Gel 1 and 2 showing the PCR products in the different lanes.

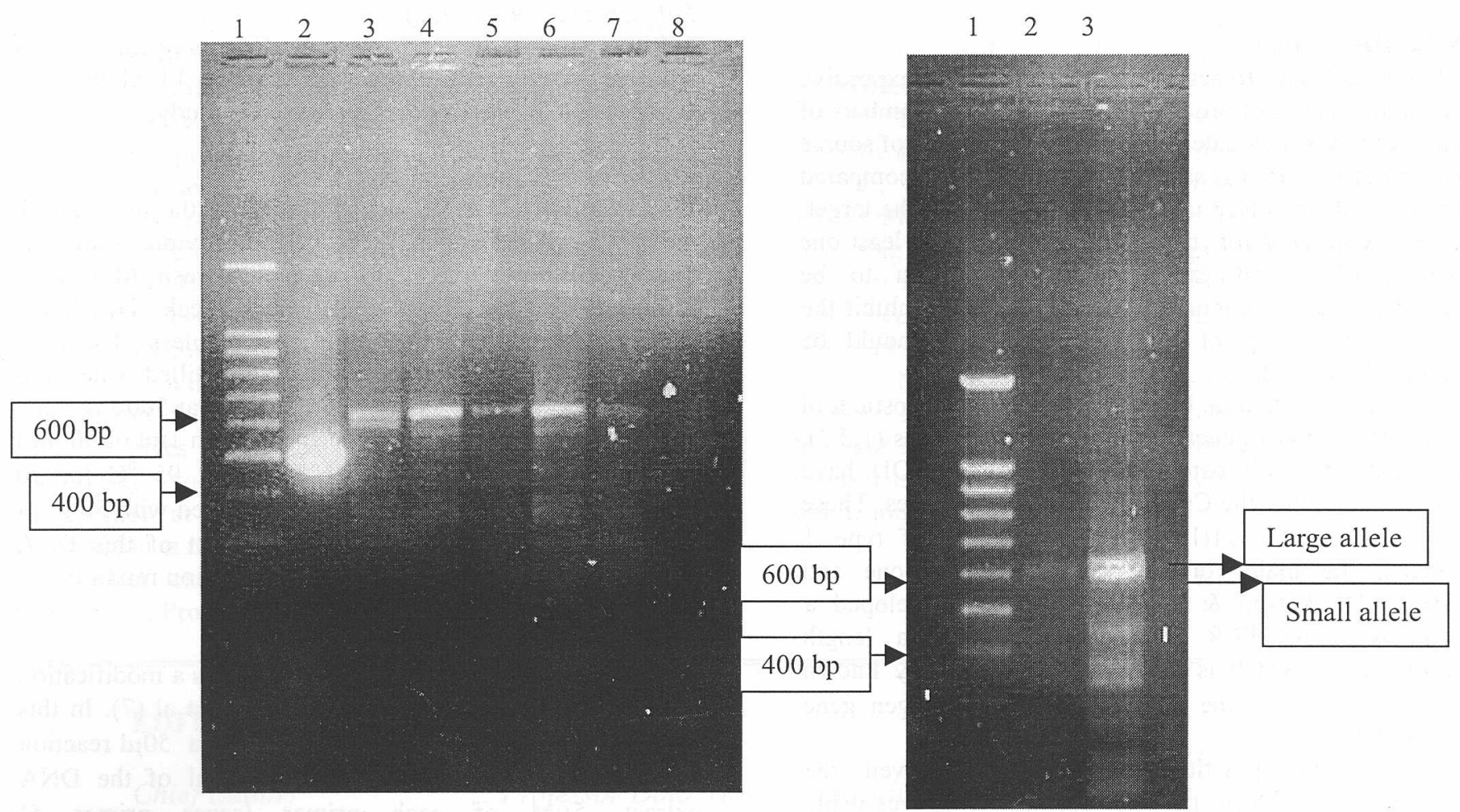

Lane 1-100bp ladder

Lane 2-positive control

Lane 3-heterozygous

Lane 4-homozygous for the large allele

Lane 5-homozygous for the large allele

Lane 6-homozygous for the large allele

Lane 7-homozygous for the large allele

Lane 8-negative control
Lane 1-100bp ladder

Lane 2-homozygous for the small allele

Lane 3-heterozygous 
Table I - The distribution of the homozygous and heterozygous alleles in various ethnic group of the student population studied. The number in () refers to the number students used in the study.

\begin{tabular}{|c|c|c|c|}
\hline Ethnic group & $\begin{array}{c}\text { Homozygous for large } \\
\text { allele }\end{array}$ & $\begin{array}{c}\text { Homozygous for small } \\
\text { allele }\end{array}$ & Heterozygous \\
\hline Malay (14) & 11 & - & 3 \\
\hline Chinese (15) & 12 & - & 3 \\
\hline Indian ( 7) & 3 & 2 & 3 \\
\hline
\end{tabular}

\section{CONCLUSION}

The experimental protocol designed is most suitable for teaching the Science, Dental and Medical undergraduates the application of PCR in genetic screening. It will give them a hands-on experience in doing PCR and an understanding of the application of PCR techniques in screening of gene-related diseases.

\section{REFERENCES}

1. Mullis, KB and Faloona FA. Specific synthesis of DNA in vitro a polymerase-catalysed chain reaction. Methods Enzymol 1987; 155: 335-350.

2. Erlich, HA (Editor). PCR technology: Principles and application for DNA amplification 1989; Stockton Press, New York, New York.
3. Innis, MA, Gelfand, DH, Sninsky, JJ and White TJ (Editors). PCR protocols: A guide to methods and applications 1990; Academic Press, San Diego.

4. Kurisu K \& Tabata MJ. Oral Diseases 1977; 3: 223 228. Macmillan Publishers Ltd, 1977.

5. Watson CJ \& Dalgleish R. PCR detection of a 38 bp length variant in the COL $1 \mathrm{~A} 2$ gene. Nucl Acids Res 1990; 18: 5925 .

6. Dalgleish R, Williams $G$ and Hawkins JR. Length polymprphism in the pro alpha 2 (I) collagen gene: an alternative explanation in a case of Marfan Syndrome. Hum Genet 1986; 73: 91-92.

7. Palmer BR and Healy JP. Development of a practical illustrating the use of the polymerase chain reaction for genetic testing. Biochem Education 1993; 21 (2): 106-107. 